\title{
SOME METAPHYSICAL IMPLICATIONS OF HEGEL'S THEOLOGY
}

\author{
PAUL REDDING \\ University of Sydney
}

\begin{abstract}
This paper examines Hegel's claim that philosophy "has no other object than God" as a claim about the essentiality of the idea of God to philosophy. On this idealist interpretation, even atheistic philosophies would presuppose rationally evaluable ideas of God, despite denials of the existence of anything corresponding to those ideas. This interpretation is then applied to Hegel's version of idealism in relation to those of two predecessors, Leibniz and Kant. Hegel criticizes the idea of the Christian God present within his predecessors in terms of his own heterodox reading of the Trinity in order to resolve a paradox affecting them - the "paradox of perspectivism".
\end{abstract}

Hegel makes claims about the relation of philosophy to religion that might raise concerns for those who want to locate his philosophy generally within the modern enlightenment tradition. For example, at the outset of his Lectures on Aesthetics he claims that philosophy "has no other object but God and so is essentially rational theology". ${ }^{1}$ What might seem to placate worries here is that Hegel of course differentiates between the forms of religious and philosophical cognition in which such a content is presented: while religion grasps this content in the form of imagistic

\footnotetext{
${ }^{1}$ G. W. F. Hegel, Aesthetics: Lectures on Fine Art, trans. T. M. Knox (Oxford: Oxford University Press, 1975), p. 101. Original German: G. W. F. Hegel, Werke in zwanig Bänden, edited by Eva Moldenhauer and Karl Markus Michel (Suhrkamp Verlag, Frankfurt am Main, 1969), vol. 13, p. 139. (Hereafter given in parentheses by volume and page numbers.) Philosophy, along with art and religion, belongs to what he refers to as "Absolute Spirit", and these three realms having this same content - God - "differ only in the forms in which they bring home to consciousness their object, the Absolute." Ibid.
} 
or figurative representations [Vorstellungen], philosophy grasps it within conceptual thought, an attitude which could seem to align him with that found within the German Enlightenment, for example, as in Lessing or Kant. However, it seems undeniable that, in comparison to Kant, for example, Hegel employs forms of expression for the presentation of his own philosophical thought that are redolent with the type of imagistic and figurative locutions supposedly at home in religion. Moreover, the actual imagery employed seems to refer to the type of trinitarian version of Christianity that can seem antithetical to those more deistic forms of Christian thought that lent themselves to the sort of "demythologization" characteristic of the enlightenment attitude to religious doctrine. Such factors as these make it easy to portray Hegel's philosophy as a disguised theology with a content from revealed religion, thus aligning him more to the spirit of the Counter-Enlightenment than the Enlightenment.

This may be an easy impression to get, but on examination it is, I suggest, a misleading one. Hegel's attitude to the relation of philosophy to religion may not be typical of the Enlightenment, but its apparent regressive features might be understood from another more favourable angle - that of an enlightened critique of the enlightenment attitude to religion. In order to consider this other possible way of understanding Hegel here, the claim about God being the content of all philosophy might be taken as signalling some purportedly irreducible role played for Hegel by the idea of God, not just in his own philosophy, but in philosophy per se, even in forms of philosophy that deny the existence of God. After all, a comprehensive philosophy that rules out the existence of God - forms of scientific materialism, for example - presumably must have conceptions of that whose existence is being denied. Moreover, we might think of those contexts in which secular philosophies seem to appeal to some quasi-theological idea in making some purportedly non-theological point, as when epistemologists frame questions about objective knowledge in terms of the "God's eye view". It is hardly surprising that, being an idealist, Hegel would be concerned with the adequacy or otherwise of such ideas, even when the they are not caught up with explicitly theological questions of God's existence.

It is the possibility of reading Hegel's thoughts on religion in this generally "meta-enlightened" way that I shall be concerned with in this paper. In its first part, I will quickly sketch in a case for the prima facie plausibility of such a claim, and then turn to the significance this claim might have for philosophy, were it to be established. The thought 
here is that if philosophy per se presupposed some idea of God, then, presumably, different philosophical orientations might be compared in terms of the relative adequacy of those ideas in a way that swings free from questions of their commitment to the existence of God. I will then go on in the second part of the paper to give this thought more substance by comparing the ways different ideas of God function within three central figures of the modern idealist tradition, Leibniz, Kant and Hegel himself.

Of course, on the reading I'm suggesting, what is meant by "adequacy" here could only be a matter of adequacy in terms of the usual sorts of criteria employed in philosophy, such as that of conceptual coherence. From the viewpoint of philosophy itself, there presumably could be no place for a right conception of God coming from outside philosophical thought, say from the content of some particular religious creed or other. Of course one might still expect the particular ideas of God to be found in any individual's philosophy as having had their origin in particular religious or irreligious traditions. Hegel's idea of God indeed has features of the God of the particular confession within which he was raised, a form of Lutheran Protestantism that seems to have been characteristic of the Swabian regions of southern Germany. But this is hardly surprising: from where else would one expect them to have come? Hegel of course portrays his own religion as the "consummate" religion, but the question I'm interested in here is that of the philosophical entitlement Hegel may claim in endorsing the particular idea of God found in that religion. ${ }^{2}$ It is in relation to this question that I will examine the use to which he puts his idea of God in attempting to resolve problems within the thought of his idealist predecessors, Leibniz and Kant.

Leibniz, a Catholic-leaning Lutheran, had devoted considerable energy to defending trinitarian Christianity against attacks coming from seventeenth-century Unitarians or "Socinians", who appealed to what is standardly taken to be a more progressive or rationalistic idea of God, a conception of God untroubled by the apparent contradiction

${ }^{2}$ We might think of this distinction as paralleling the familiar one in philosophy of science between considerations relevant to the "context of discovery" and those to the "context of justification". That the central idea of some theory, say, came to its discoverer in a dream, would by itself hardly warrant dismissing the theory as irrational. Typically, it is thought, it is how the scientist goes about establishing and justifying the theory that is crucial. 
of the trinity doctrine. ${ }^{3}$ I will suggest that we can understand Hegel's claim for the superiority of this trinitarian God when we see the way in which it can be used to address implicit problems within Leibniz's own metaphysics, problems that had been made explicit in the views of Kant. Ultimately, were it possible to make a case for Hegel's success here, his approach would, I will suggest, be of more than historical relevance. Not only can the problems in Leibniz and Kant addressed by Hegel be recognized within much contemporary philosophy, they can be seen to be bound up with similar ideas of God that Hegel wants to challenge and replace. ${ }^{4}$

\section{PHILOSOPHY AND THE IDEA OF GOD}

I think it can be said that throughout a large part of its history, much of what we take as belonging to Western "philosophy" has accepted as legitimate appeals to a monotheistically conceived god of one variety or another. Consider, for example, the role played by Plato's artificer in his Timeaus, or Aristotle's prime mover in his Metaphysics. As for medieval philosophy, the idea that it was drenched in theological assumptions is rarely if ever disputed, and relatively recently historians have turned to the theme of the persistence of this theological content into the early modern period. ${ }^{5}$ Moreover, despite the increasing secularization of philosophy from the eighteenth century, it's still not difficult to find explicitly theological interpretations of central philosophical ideas well into our own time. To give just one example, the British philosopher Michael Dummett has stated that as a Catholic he is committed to the idea of an omniscient God and so to the existence of a world of things in themselves that would be the objects of the knowledge had by such a God. But as a philosopher, he notes, he is independently committed to the existence of things in themselves, and by inference to the existence

\footnotetext{
${ }^{3}$ On this Leibniz commitment to trinitarianism, see Maria Rosa Antognazza, Leibniz on the Trinity and the Incarnation: Reason and Revelation in the Seventeenth Century, trans. Gerald Parks, (New Haven: Yale University Press, 2007).

${ }^{4}$ What I won't be doing will be to go on to address the further question of the existence of God for Hegel. My sole concern will be with establishing some of the consequences that the "the idea" of God will have for an idealist such as Hegel.

${ }^{5}$ See, for example, Amos Funkenstein, Theology and The Scientific Imagination from the Middle Ages to the Seventeenth Century (Princeton: Princeton University Press, 1986).
} 
of an omniscient God, without which, he thinks the notion of a world of things in themselves would be meaningless. ${ }^{6}$

The way in which Dummett conceives of getting to the existence of God from philosophical premises may not be common in contemporary analytic metaphysics, although even in this domain, claims for theism as a philosophically acceptable position seem to have made a very definite comeback over the past decades. ${ }^{7}$ Beyond contexts in which such explicit theistic content is dealt with, however, it is not difficult to find ones in which ideas of God still continue to play important roles. Besides the ubiquitous "God's eye point of view" already mentioned, one might note the use of the notion of omniscience within the sorts of thought experiments that are commonly used in the defence or critique of metaphysical theories. As an example of this, we might take Frank Jackson's celebrated case of Mary, the fabulously talented neuroscientist who has grown up in an entirely black and white environment, and who consequently doesn't know what it is like to see colours such as the colour red. ${ }^{8}$ In Jackson's thought experiment, Mary knows "everything there is to know about the physical nature of the world", 9 and yet she doesn't know all there is to know about colour and its perception. Before leaving her black and white environment, she has something to learn, the

6 "No one who believes in God can dismiss [the notion of things in themselves], however: the way things are in themselves must be the way in which God apprehends them. ... But can the notion be explained or defended at all without appeal to God's knowledge of the world, and hence by anyone who denies that God exists? In my opinion, it cannot: the price of denying that God exists is to relinquish the idea that there is such a thing as how reality is in itself." Michael Dummett, The Nature and Future of Philosophy (New York: Columbia University Press, 2010), p. 44.

7 Thus Quentin Smith, in “The Metaphilosophy of Naturalism”, Philo: A Journal of Philosophy, vol. 4, no. 2 (2001), pp. 195-215, has suggested that analytic philosophy has undergone the process of desecularization over the last three or four decades sparked off by the appearance of Alvin Plantinga's God and Other Minds: A Study of the Rational Justification of Belief in God (Ithaca: Cornell University Press, 1967).

${ }^{8}$ Frank Jackson, “Epiphenomenal Qualia”, The Philosophical Quarterly, vol. 32, no. 127 (1982), pp. 127-136, and “What Mary Didn't Know”, The Journal of Philosophy, vol. 83, no. 5 (1986), pp. 291-295.

9 Jackson, "What Mary Didn’t Know", p. 291. "She knows all the physical facts about us and our environment, in a wide sense of 'physical' which includes everything in completed physics, chemistry, and neurophysiology, and all there is to know about the causal and relational facts consequent upon all this, including of course functional roles." Ibid. In the earlier paper, Jackson says that she obtains "all the physical information there is to obtain about what goes on when we see ripe tomatoes, or the sky, and use terms like 'red', 'blue', and so on". Jackson, "Epiphenomenal Qualia”, p. 130. 
phenomenal knowledge of what red, for example, looks like. ${ }^{10}$ The story of Mary here functions within an argument challenging a metaphysical theory, here that of physicalism, and the idea of Mary's local omniscience - that is, omniscience about everything that bears on colour vision - is crucial. Were Mary's knowledge of the relevant part of the physical world limited, the argument would simply not work. "It seems just obvious", Jackson says of Mary, regarding her first colour experience, "that she will learn something about the world and our visual experience of it. But then it is inescapable that her previous knowledge was incomplete. But she had all the physical information. Ergo there is more to have than that, and Physicalism is false". ${ }^{11}$

I don't want to engage with Jackson's story any further than to note the implicit appeal to an idea of God by way of an appeal to a standard property of God, that of the attribute of omniscience, even if this omniscience is limited to a particular realm - that of colour and colour vision. There is, after all, a qualitative difference between the hypothetical Mary and actual neuroscientists, who, while extremely knowledgeable, are hardly omniscient about the topic in question. Jackson's implicit appeal to this theological concept is not like Dummett's, of course. Dummett appeals to an actual God to make meaningful a conception of the world to which he is philosophically committed. For Jackson, godly omniscience is invoked as a mere logical possibility: all that is needed for his argument is the idea of a logically possible world containing the purportedly omniscient Mary. But I want nevertheless to take this example as instantiating the type of point Hegel makes. The logically possible omniscience Jackson appeals to is an attribute of a God qua object of a rational theology, and it is an idea, moreover, that has a long history. One finds it, for example, in both Galileo and Newton as an idealized model for the epistemic goal which makes the modern idea of the systematic growth of scientific knowledge intelligible.

One example hardly establishes a case, but hopefully what I have said might be enough to allow a general idea of how, on this interpretation, Hegel's claim that all philosophy is, or at least contains, a "rational theology" might be plausibly pursued, and with this I want to now turn

${ }^{10}$ Jackson's approach here links to, but has significant differences from, that found in Thomas Nagel, "What is it like to be a bat?", The Philosophical Review, 83 (1974), pp. 43550. See, Jackson, “Epiphenomenal Qualia”, p. 131, footnote 10.

${ }^{11}$ Jackson, “Epiphenomenal Qualia”, p. 130. 
to a sketch of a role played by the idea of God in the respective approaches of first, Leibniz and Kant, and then, Hegel.

\section{THEOLOGY AND METAPHYSICS IN PRE-HEGELIAN IDEALISM}

The eighteenth-century European Enlightenment clearly represented a major challenge to the generally theistic flavour of much earlier philosophy. In Germany the enlightenment attitude to religion was generally to portray religion as presenting important truths, in particular moral truths, in some indirect, metaphorical or generally figurative way. Such an attitude is present in G. E. Lessing, for example, who, drawing on Leibniz's philosophy, had portrayed the revealed content of Christianity to be literally false, but as providing, as one commentator puts it, a "partial, perspectival adumbration of this ultimate truth" - that is, the truth presented philosophically in Leibniz's monadological metaphysics. ${ }^{12}$ Humans as "limited gods" [eingeschrängte Götter], as Lessing portrayed them, ${ }^{13}$ are versions of Leibniz's finite monads able to cognize from their particular "points of view" what God could grasp from an infinity of such points of view. But Lessing had added the dimension of an historical education for the human species, now portraying the Christian myth as containing some truth, but not a truth without qualification - rather, truth in a form appropriate for the species at a phase of their development, located at some "particular, historically determined point of view" ${ }^{14}$ It is not difficult to see, however, the problem lurking for this approach to metaphysics - if metaphysical knowledge is conceived as God's knowledge, then how is it available to us finite knowers, and so how are we to access the standard against which religion is to be compared? Kant was famously to make this epistemic problem explicit. For him, we finite human cognizers are by necessity incapable of the type of knowledge of things in themselves that Leibniz's monadology was meant

${ }^{12}$ Henry Allison, Lessing and the Enlightenment: His Philosophy of Religion and Its Relation to Eighteenth-Century Thought (Ann Arbor: University of Michigan Press, 1966), p. 133.

${ }^{13}$ In a set of notes seemingly written in 1752-3 and later published under the title, "The Christianity of Reason", G. E. Lessing, Philosophical and Theological Writings, translated and edited by H.B. Nisbet (Cambridge: Cambridge University Press, 2005), p. 28.

${ }^{14}$ Allison, Lessing and the Enlightenment, p. 134. This historical development is the theme of Lessing's Die Erziehung des Menschengeschlechts. G. E. Lessing, "The Education of the Human Race", in Philosophical and Theological Writings. 
to instantiate. But it is clear that while Leibniz had a problem with the idea of any telos of human knowledge, he nevertheless had a powerful account of the human capacity to move from more to less perspectival cognitions, an idea that was later to be found in Hegel as well as in many contemporary forms of philosophical thought. The tools for this were contained in Leibniz's particular interpretation of the concepts of "clear" and "distinct" ideas.

In one of Leibniz's favourite images from the Christian Platonist tradition, humans are "mirrors of God" such that each reflects the entire universe as known by God, but in an imperfect way. However, humans can perfect their imperfect representations in a process in which initially clear but confused ideas are rendered progressively clear and distinct. Leibniz's understanding of this notion radically departs from the approach of Descartes. ${ }^{15}$ In a well-known passage from the Discourse on Metaphysics Leibniz states that "when I can recognize one thing among others without being able to say what its differences or properties consist in, my knowledge is confused. ... But when I can explain the evidence I am using, the knowledge is distinct. An assayer's knowledge is like this; he can distinguish true from false gold by means of certain tests or marks which make up the definition of gold". ${ }^{16}$ But even the assayer's clear and distinct knowledge of gold might be only relatively distinct because the component ideas entering into his definition of gold may themselves be confused. So, "distinct knowledge has different levels, because the notions which enter into the definition usually require definition themselves, and are known only confusedly". ${ }^{17}$ There would thus seem to be a clear parallel between Leibniz's assayer and Jackson's neuroscientific Mary here. Mary is like the assayer, we may say, in that what she knows of colour goes beyond the clear but confused knowledge that the rest of us neuroscientific illiterates have when we recognize and so distinguish

${ }^{15}$ Leibniz thus frees the idea of clear and distinct ideas from the ambiguity it has in Descartes, replacing Descartes' modelling of the apprehension of a clear and distinct idea on the mind's phenomenological acquaintance with the particular contents of sensation. On this see, Graciela De Pierris, "A Fundamental Ambiguity in the Cartesian Theory of Ideas: Descartes and Leibniz on Intellectual Apprehension", Manuscrito: Revista Internacional de Filosofia, vol. 30, no. 2 (2007), pp. 383-422.

${ }^{16}$ G. W. Leibniz, "Discourse on Metaphysics" in Philosophical Texts, trans. and ed. R. S. Woolhouse and Richard Francks, (Oxford: Oxford University Press, 1998), § 24.

${ }^{17}$ Ibid. 
particular colours, but can't explain their differences. ${ }^{18}$ The twist in Jackson's story is that prior to leaving her black and white room, Mary had only clear and distinct ideas about colour; what she lacked when confined to her black and white world were clear and confused ones.

Leibniz is vague, however, as to the telos of this process of the perfectibility of human knowledge. In the Discourse on Metaphysics, he had defined an adequate idea as one in which "everything which enters into a definition or an item of distinct knowledge is known distinctly, right down to the primary notions", ${ }^{19}$ and had defined intuitive knowledge as had when "my mind simultaneously and distinctly understands all the primary ingredients of a notion". However, he notes, "this is very rare: most human knowledge is only confused or suppositive". ${ }^{20}$ In the later Monadology, however, the limitations of human knowledge are more strongly pressed: only God can have an adequate or perfect idea from which all confusion has been removed. ${ }^{21}$ We can only achieve clear and distinct knowledge in discrete areas - islets of distinct ideas, as it were within a sea of confusion. Moreover, God's complete knowledge of any part of the universe will in fact be an idea of the whole universe, as the transitions from confused to distinct ideas will contextualize the thing to be known in an ever-widening sphere of relations. It is in this sense that the substances I perceive confusedly in fact "express" the entire universe: "But since all things have a connection with others, either mediately or immediately, the consequence is that it is the nature of every substance to express the whole universe by its power of acting and being acted

${ }^{18}$ Robert Adams points out that while in the 1670 s Leibniz seemed to believe knowledge of the phenomenal quality of colour could not be explained theoretically, by the mid 1680s he had come to treat colours as confused phenomena of the sense, regarding them as complex rather than simple qualities. Robert Merrihew Adams, "The Priority of the Perfect in the Philosophical Theology of the Continental Rationalists", in Michael Ayers (ed.), Rationalism, Platonism and God (Oxford: Oxford University Press, 2007), pp. 110-111.

${ }^{19}$ Leibniz, "Discourse on Metaphysics", $\$ 24$.

${ }^{20}$ Ibid., first emphasis added.

21 "Because, in organizing the whole, God has regard to every part, and specifically to ever monad; and since a monad is representative in its nature, nothing could restrict it to representing only a part of things. But it is of course true that this representation of the details of the whole universe is confused, and can only be distinct with respect to a small part of things, namely those which are either closest or largest in relation to each monad. Otherwise every monad would be divine. ... They all reach confusedly to infinity, to everything; but they are limited and differentiated by their level of distinct perception." G. W. Leibniz, Monadology, \$60, in Philosophical Texts, p. 276. 
on, that is, by the series of its own immanent operations". ${ }^{22}$ This brings into focus a further position on the continuum on which we find the distinction between clear and confused and clear and distinct cognitions. When I perceive some substance, say, this plant before me, in a clear but confused way, I am in fact grasping the universe itself, although not consciously. In Leibniz's epistemic taxonomy I am perceiving it in an obscure way. ${ }^{23}$

But this now establishes a tension within the idea of the relation of human to divine knowledge - that is, in relation to an entirely distinct idea of the world that God, as omniscient, represents - and so the idea of the very possibility of metaphysical knowledge itself. How can we be possibly entitled to the account presented in Leibniz's own monadology if we are somehow ultimately bound to our finite perspectives? If, as God's creatures, we are necessarily limited to confused ideas about substances and obscure ideas of the universe itself, how are we to know what the world might be like for God? ${ }^{24}$ Unable to form a distinct aperspectival idea of the whole against which my view can be grasped as confused and perspectival, how can I be self-conscious of my own perspectivity? We might call this problem the paradox of "perspectivism".

Kant's response to this Leibnizian paradox was simple in that he replaced the vague quantitative difference between human and divine knowledge with a qualitative one between distinct forms of knowledge. Kant thus portrays God as a being capable of the rational intuition of

${ }^{22}$ G. W. Leibniz, "A Specimen of Discoveries About Marvellous Secrets", in Philosophical Writings, ed. G. H. R. Parkinson, trans Mary Morris and G. H. R. Parkinson (London: Dent, 1973), p. 84.

${ }^{23}$ Leibniz had used the obscure cognitions in the 1684 publication "Mediations on Knowledge, Truth, and Ideas", in Philosophical Essays, trans. Roger Ariew and Daniel Garber (Indianapolis: Hackett, 1989), where he notes that "a notion which is not sufficient for recognizing the thing represented is obscure, as, for example, if whenever I remember some flower or animal I once saw, I cannot do so sufficiently well for me to recognize that flower or animal when presented and to distinguish it from other nearby flowers or animals". Ibid., pp. 23-4. The notion of obscure ideas is found in Ralph Cudworth, True Intellectual System of the Universe (London: Richard Royston, 1678, facsimile reprint, Hildeschiem: Georg Olms Verlag, 1977), p. 160.

${ }^{24}$ Leibniz's later writings seem to admit of contradictory "corporeal" and "idealist" readings of the monadology - an ambiguity might be seen as reflecting this problem. For a defence of the traditional "idealist" reading of Leibniz see Robert Merrihew Adams, Leibniz: Determinist, Theist, Idealist (Oxford: Oxford University Press, 1994), and for a thorough-going critique, see Pauline Phemister, Leibniz and the Natural World: Activity, Passivity and Corporeal Substances in Leibniz's Philosophy (Dordrecht: Springer, 2005). 
"things in themselves", while we humans have to rely on our being causally effected by worldly substances, the resulting sensations produced in us being somehow incorporated into representational structures to which we have contributed the forms. Without these representational forms contributed by us, we can have no knowledge at all; but the fact that we are the source of the forms of what is known means that what we know is never the world as it is "in itself". Leibniz had distinguished the knowledge of the world as phenomena, achievable in science, from the deeper level of metaphysical knowledge underlying and explaining the phenomena, but Kant now limits our theoretical knowledge to the former, understood as the systematically organized knowledge of appearances.

In short, Kant clarified what had been vague and ambiguous in Leibniz's approach, concerning the relation of human to divine knowledge. But the resulting scepticism over the status of metaphysical knowledge of things in themselves posed well-known problems for Kant. First, Leibniz's paradox of perspectivism seems to re-emerge, as is captured in Jacobi's famous quip about Kant's "things in themselves". Without this notion, claimed Jacobi, one cannot enter the system of Kant's transcendental idealism, but with it one could not remain within it. ${ }^{25}$ Jacobi could thereby draw further consequences of this for the familiar Lessingian attitude to the relation of religious myth to philosophy. From Jacobi's point of view, by reducing them to appearances, Kant has denied us knowledge of even the most fundamental objects of experience. Realism about the everyday world is thus underpinned by a kind of faith. But if belief in the reality of even such everyday objects requires a kind of faith, why cannot this faith be extended to belief in God. ${ }^{26}$ Once Lessing's construal of religion as a partial and perspectival figurative representation of the world in itself, which reflects the limitations of our spatial and temporal location in the world has been deprived of its philosophical contrast - a knowledge of things in themselves - what is there to prevent it from being simply accepted as the best we can achieve? ${ }^{27}$

${ }^{25}$ Thus Jacobi notes that "das ich ohne jene Voraussetzung in das System nicht hineinkommen, und mit jener Voraussetzung darinn nicht bleiben konnte". Friedrich Heinrich Jacobi, David Hume über den Glauben, oder Idealismus und Realismus. Ein Gespräch (Breslau: G. Loewe, 1787), Beilage, p. 223.

${ }^{26}$ As is often pointed out, Jacobi could purport to employ Hume in this affirmation of a fundamentally fideistic outlook because the German word "Glaube" blends the meanings of both "belief" and "faith".

27 There had been, after all, a long tradition within Christian theology of appeals to analogy and other figurative forms of thought in the attempt to characterize religious knowledge itself. 
Kant's sceptical epistemology of metaphysical knowledge had opened a space within which overtly counter-Enlightenment dogmatic reassertions of religious dogma could return, but Kant could respond to this in a distinctive way by boldly relocating the metaphysical project itself within the domain of practical rather than theoretical reason, and treating religious content as a figurative presentation of this distinctly moral knowledge. Thus, for Kant, while it is impossible for us to determine our beliefs entirely rationally without any empirical input, it is nevertheless possible for each of us as finite rational beings to determine our wills in this way. We can know how we ought to act from reason, and can be motivated to act in such ways from reason, even though we can never be assured from some theoretical perspective of how it is we can do this. Distinctly moral knowledge of how to act is formulated in the linguistic form of the imperative, not that of the declarative, giving Kant an alternative to the idea of metaphysical knowledge as representation of the world. As a consequence, Kant could now reinterpret the generally Lessingian model of religious myth as an indirect form of knowledge, and as such as subordinate to conceptual knowledge, albeit conceived as practical rather than theoretical. ${ }^{28}$ Kant was able, we might say, to square the Lessingian circle, demythologizing religion without the need to contrast it with a positive metaphysical content that literalizes its figurative claims. Hegel's thought, I suggest, started from a similar place, but rapidly veered in a different direction, allowing him more adequately to confront the paradox of perspectivism.

\section{HEGEL ON "REPRESENTATION"}

Like Kant, Hegel discusses religion as involving a type of symbolic presentation of truths that in philosophy are expressed purely conceptually. While the form of this content in religion is Vorstellung,

${ }^{28}$ Thus portraying religious representation as in a generally symbolic mode, Kant could portray Jesus as a type of moral "prototype" in whom we could recognize the morality of which we ourselves capable. That is, what we recognize in Jesus when we figuratively represent him as the "son of God" is a prototype that "is nowhere to be sought except in our reason". Immanuel Kant, "Religion within the Boundaries of Mere Reason", in Religion and Rational Theology, translated and edited by Allen W. Wood and George Di Giovanni (Cambridge: Cambridge University Press, 1996), p. 106. (Original German in Kants Gesammelte Schriften (Berlin: Preussische Akademie der Wissenschaften, 1900-), vol. 6, p. 64. Hereafter, pagination to the German original will be given in the form, 6:64.) 
"representation", in philosophy it attains the form of thought. But while it might be thought that this distinction comes down to something like a distinction between "figurative" and "literal" truths, this is not the case. Representation is, Hegel says in the 1827 Lectures on the Philosophy of Religion "a consciousness of something that one has before oneself as something objective", 29 and in his discussion of theoretical spirit in the Lectures on the Philosophy of Spirit from around the same time he notes that "the content of representation is given, it is something immediately found [Vorgefundenes].... In representation there is a sensible, immediate givenness, and the element of freedom, namely, that this content is my representation. ... However I have not made the content. The content possesses an element of immediacy, givenness, of not being posited through my freedom". 30

For Hegel, representation as such is not at all a cognitive mode that is exclusive to religious thought, it is simply the form that a cognitive content takes in everyday life, the prototype of which is the way in which some thinkable content is made present as sensible and immediate in perception, in which we understand some thinkable content as simply given and, as it were, forced upon us. It is this prototypically perceptual content that is captured in the "images" that Hegel thinks of as the principle mode of representational content and as "taken from immediate intuition". ${ }^{31}$ For Hegel, I suggest, "representation" plays something of the same role as played in Leibniz by the idea of something known in a clear but confused way. Religion is representational because in it some universal content is made present for thought by, as it were, piggy-backing in a figurative or metaphorical way on this everyday type of representational vehicle. When some perceptual content is reproduced in images, Hegel says in

${ }^{29}$ G. W. F. Hegel, Lectures on the Philosophy of Religion, One-Volume Edition, The Lectures of 1827, edited by Peter C. Hodgson, translated by R. F. Brown, P. C. Hodgson, and J. M. Stewart, with the assistance of H. S. Harris, (Berkeley: University of California Press, 1988), p. 144. Original German: G. W. F. Hegel, Vorlesungen: Ausgesählte Nachschriften und Manuskripte, ed. Walter Jaeschke (Hamburg: Felix Meiner Verlag, 1983-5), vol. 3, p. 292. Hereafter given in the form V followed by volume and page number.

${ }^{30}$ G. W. F. Hegel, Lectures on the Philosophy of Spirit, 1827-8, translated with an introduction by Robert R. Williams, (Oxford: Oxford University Press, 2007), p. 213. Original German, Hegels Vorlesungen über die Geistes 1827/8, ed. Franzo Hespe and Burkhard Tuschling (Hamburg: Meiner Verlag, 1994), pp. 195-6, hereafter given in parentheses as "VG" followed by page number.

${ }^{31}$ Hegel, Lectures on the Philosophy of Religion, 1827, p. 145 (V3:293). 
the Lectures on the Philosophy of Religion, "we are directly conscious that they are only images but that they have a significance distinct from that which the image as such primitively expresses - that the image is something symbolic or allegorical and that we have before us something twofold, first the immediate and then what is meant by it its inner meaning". "Thus", he goes on, "there are many forms in religion about which we know that they are only metaphors". 32

Religion uses the vehicles of everyday representational contents in order to present its truths, and this very fact reveals that the distinction between the literal and the figurative is one made within the mode of representation. A photograph of a gleaming new car can represent that particular car, or more generally, the model exemplified by that particular car, or, figuratively, abstract entities like wealth or a lavish lifestyle. But it can express these more general meanings because in the first place it can represent that car itself: as Freud purportedly claimed, "sometimes a cigar is just a cigar". ${ }^{33}$ In short, the distinction between literal and figurative is one that works within "representation", rather than between representation and thought. But if the philosophical conceptual reinscription of religious content cannot be thought of as the transition from figurative to literal meaning, how should it be conceived? The clue to this is to be found, I suggest, in the type of movement that Leibniz thinks of in terms of making clear and confused ideas clear and distinct.

In the Lectures on the Philosophy of Religion Hegel says that thought "dissolves the form of the simple, in which the content is found in representation, in such a way that distinct determinations within this simple reality are grasped and exhibited so that it is known as something inwardly manifold". ${ }^{4}$ This theme of thought's taking apart of the apparently simple givennesses of representation is similarly found in the Lectures on the Philosophy of Spirit. "I have a representation of something; this means that I do not yet know the object in its specificity. Definition requires that I state the species, the universal, and also state the determinacy, the essential determination. In so doing, I have gone beyond the form of representation to the determination of the concept." ${ }^{35}$ Moving from a simple experience or representation of something to a form of thought

\footnotetext{
${ }^{32}$ Ibid., p. 145-6 (V3:293).

${ }^{33}$ This is, I believe, apocryphal.

${ }^{34}$ Ibid., p. 152 (V3:299).

${ }^{35}$ Hegel, Lectures on the Philosophy of Spirit, 1827-8, pp. 213-4 (VG:196).
} 
involving its conceptual articulation in terms of a definition combining a universal and its relevant differentiae is just what Leibniz had thought of in terms of making a clear but confused idea clear and distinct. In more contemporary terms, it is what Jackson means by the transition from the perspectivally limited experiential knowledge of coloured things to a scientific understanding of them. Like Kant, Hegel thinks of perceptual experience as implicitly structured by concepts, and it is this implicit conceptuality of experience that is made explicit when I make a judgment on the basis of experience, and express this judgment in words. But this is to bring the perceptual content into the "space of reasons", that is, to give it a logical form that enables the judgment to be inserted into a chain of reasoning - an inference. However, this must involve a certain loss, since the singular terms that purportedly would pick out the phenomenal properties of whatever it is I'm perceiving have no place in such a thinkable content. When I raise to thought that which appears as this, here, now, I have left the perspectival singularity it has as experienced, behind. As with Leibniz, for Hegel the movement from representation to thought looks like a movement towards the type of knowledge that is traditionally attributed to God. ${ }^{36}$ Kant had responded to the ambiguity of Leibniz on the relation of human to divine knowledge by drawing a boundary between these two possible forms of knowledge. Hegel's response, I suggest, is by way of a criticism of the implicit idea of God that Kant accepts in making this very demarcation.

\section{THE IDEA OF GOD IN KANT AND HEGEL}

In the section of the Critique of Pure Reason on the "transcendental ideal" or "transcendental prototype", ${ }^{37}$ Kant portrays the "idea of God" as generated from a type of inferential thinking whose form is captured by the disjunctive syllogism. In theoretical reason, "ideas", that is, concepts regulating inferential thought processes, are limited to this regulative

${ }^{36}$ For an account of the way in which Leibniz conceives of our knowledge of the mysteries of revealed religion as a form of clear but confused cognition see Marcelo Dascal, "Reason and the Mysteries of Faith: Leibniz on the Meaning of Religious Discourse" in Leibniz: Language, Signs and Thought. A Collection of Essays (Amsterdam: John Benjamins, 1987), pp. 93-124.

${ }^{37}$ Immanuel Kant, Critique of Pure Reason, translated and edited by Paul Guyer and Allen W. Wood (Cambridge: Cambridge University Press, 1998), Division two, Book II, Chapter III, section II. 
function, and deprived of any knowledge-forming or predicative function. Under the influence of the transcendental illusion, however, these "ideas" are taken as representing some kind of supersensible thing. Here, the idea organizing the rational relations among all determinate objects captured by the disjunctive syllogism is taken as designating a "highest being" which provides the ground of all finite things. More specifically, the "ideal" of God results from the "realization", "hypostatization" and "personalization" of this properly formal set of relations holding among all completely conceptually determined objects. ${ }^{38}$ It is easy to recognize various candidate gods in Kant's description. Simply realizing the idea, as in Kant's idea of the omnitudo realitatis, would result in something like Spinoza's absolute substance with its two attributes of thought and extension. Further personalizing the idea would now represent it in more anthropomorphic terms, as traditional personalistic forms of monotheism, and perhaps hypostatizing would result in something like the traditional Christian trinitarian conception of God, with its multiple "persons". ${ }^{39}$ But for Kant such sensibilized ideas of God can play no epistemic role at all. As far as the trinitarian view of God goes, he points out later in The Conflict of the Faculties, when taken literally this doctrine "has no practical relevance at all ... Whether we are to worship three or ten persons in the Deity makes no difference". ${ }^{40}$ It is only when we read a specifically moral meaning into this article of faith that it would contain an intelligible belief that "refers to our moral vocation". For example, in Religion Within the Boundaries of Mere Reason, the trinity is seen as symbolizing the various relations within which an individual stands to the moral law which it simultaneously legislates and obeys, ${ }^{41}$ and the same interpretative approach holds true of the associated doctrine of the incarnation. Were we to think of the Deity as "dwelling incarnate" in a real human being and working as a second nature in him, then we can draw nothing practical from this mystery: since we cannot require ourselves to rival a God, we cannot take him as an example". ${ }^{42}$ It is only by

\footnotetext{
${ }^{38}$ Kant, Critique of Pure Reason, A583/B611n.

${ }^{39}$ The Nicene Creed had settled on an account of the trinity as three "hypostases" in one "ousia".

${ }^{40}$ Immanuel Kant, "The Conflict of the Faculties", in Religion and Rational Theology, p. $264(7: 39)$.

${ }^{41}$ Immanuel Kant, "Religion Within the Boundaries of Mere Reason", in Religion and Rational Theology, pp. 166-7 (6:140-2).

${ }^{42}$ Kant, "The Conflict of the Faculties", in Religion and Rational Theology, p. 265 (7:39).
} 
taking Jesus "as the Idea of Humanity in its full moral perfection, present in God from eternity and beloved by him", ${ }^{43}$ rather than as an actual man who is God, that we could take his life as embodying moral examples we could follow.

Hegel likewise thinks of the doctrines of the Trinity and the Incarnation as employing figurative forms of thought, but for him the significance of this content so presented could not be more different, being representational presentations of important metaphysical truths no longer restricted to the realm of morals. Hegel is critical of the idea of reducing the significance of Jesus to the status of anything like a moral exemplar: rather, the significance of the doctrine of Jesus as the second person of the trinity resides in the fact that God necessarily assumes human form and, thereby, suffers and dies. "God has died, God is dead", Hegel famously declares in his Lectures on the Philosophy of Religion from 1831, and goes on "this is the most frightful of all thoughts". That the death of a man signifies God's death is, of course, a representation, and a more conceptual way of expressing this truth is to be found in Hegel's further expansion of the idea in the claim "that everything eternal and true is not, that negation itself is found in God". ${ }^{4}$ Four years earlier, quoting the words "God himself is dead" from the Lutheran hymn of Johannes Rist, Hegel interprets these words as expressing "an awareness that the human, the finite, the fragile, the weak, the negative are themselves a moment of the divine, that they are within God himself, that finitude, negativity, otherness are not outside of God and do not, as otherness, hinder unity with God. Otherness, the negative, is known to be a moment of the divine nature itself. This involves the highest idea of spirit." ${ }^{45}$

On the logical issue of negation, Hegel's thought stands in stark contrast to that of Kant, who in his discussion of the idea of God in "The Transcendental Ideal" says that "all negations ... are mere limitations of a greater and finally of the highest reality; hence they presuppose

${ }^{43}$ Ibid. That is, "present in God" as an idea. Kant thus gives to the trinity doctrine a singularly "immanent" meaning, without reference to creation.

${ }^{44}$ Hegel, Lectures on the Philosophy of Religion, vol. III, The Consummate Religion, edited by Peter C. Hodgson, translated by R. F. Brown, P. C. Hodgson, and J. M. Stewart, with the assistance of H. S. Harris (Berkeley: University of California Press, 1985), p. 323n (17:291).

${ }^{45}$ Ibid., 326 (17:297). 
it, and as regards their content they are merely derived from it." ${ }^{36}$ As Henry Allison points out, with this claim Kant accepts the logical and ontological prioritization "of realities or positive predicates over negative ones" ${ }^{47}$ We can appreciate this fact when we see how, if one simply "realizes" Kant's idea of God as the ground of all determinations, without further "hypostatizing" or "personalizing" it, one seems to find Spinoza's divine substance in which all determinations are negations of a single positively conceived substance. But Hegel criticizes this prioritizing of positive concepts over negative ones, as he criticizes, for example, the "affirmative principle" found in Plato in which the Idea is conceived "as only abstractly identical with itself", and praises Aristotle for making conspicuous "the moment of negativity, not as change, nor yet as nullity, but as difference or determination". 48

This critique of the logical principle of abstract self-identity can be seen in Hegel's attraction to the portrayal of the Trinity in the writings of

46 "Thus all the possibility of things ... is regarded as derivative, and only that which includes all reality in it is regarded as original. For all negations (which are the sole predicates through which everything else is to be distinguished from the most real being) are mere limitations of a greater and finally of the highest reality; hence they presuppose it, and as regards their content they are merely derived from it." Kant, Critique of Pure Reason, A578/B606.

${ }^{47}$ Henry Allison, Kant's Transcendental Idealism: An Interpretation and Defense, revised and expanded edition (Ann Arbor: Yale University Press, 2004), p. 399. The priority of "positive" over "negative" determinations in Kant is already signalled by his treatment of the categories of "reality" and "negation" from the "Transcendental Analytic". Kant, Critique of Pure Reason, A80-3/B106-9.

${ }^{48}$ G. W. F. Hegel, Lectures on the History of Philosophy, 3 volumes, trans. E. S. Haldane and Frances H. Simson (Lincoln: University of Nebraska Press, 1995), vol. II, p. 140 (19.153). The position that Hegel describes in terms of the priority of the affirmative principle can be seen as the view that Laurence Horn describes as the "asymmetricalist" position on the relation of positive and negative statements, asymmetricalists regarding negative statements as "less primitive, less informative, less objective, less godly, and/or less valuable than their affirmative counterparts." Laurence R. Horn, A Natural History of Negation (Chicago: University of Chicago Press, 1989), p. 3. Horn describes Plato, when speaking through the "stranger" of the Sophist as "introduc[ing] two of the recurring themes of our history: the view that negation can be eliminated by defining it away in terms of the (putatively) positive concept of otherness or difference, and the observation that negative statements are in some sense less valuable than affirmative ones, in being less specific or less informative." ibid, p. 1. Hegel's most obvious target when he attacks the concept of identity that goes with the "affirmative principle" would seem to be Leibniz. More recently, the principle of identity stressed by Frege, when understood objectually rather than metalinguistically - the principle that every thing is identical with itself might be thought of as a more recent version. 
the Christian mystic, Jacob Böhme. ${ }^{49}$ While Hegel certainly considered Böhme's expression "barbaric" and in need of translation into conceptual form, ${ }^{50}$ he nevertheless considered his account of the Trinity as capturing the basic shape of the "thought determinations" or categories of his own logic. Thus Böhme's exclusive idea, "the thought that permeates all his works - is that of perceiving the holy Trinity in everything, and recognizing everything as its revelation and manifestation, so that it is the universal principle in which and through which everything exists". ${ }^{51}$

In Böhme's triune deity, at least as Hegel portrays it, considered in abstraction the first person or "Father" is indeterminate and hidden, more akin to "the Neo-Platonic unity ... without knowledge of itself and likewise unrecognized", ${ }^{2}$ than a "person" with a personalistic will akin to the Old Testament God who had willed the material world into existence. ${ }^{53}$ In contrast, the Son is the "I", "the word, the Separator, Revelation ... the source of all difference", and importantly "the will and implicit Being which are in the powers of all natural things" ${ }^{54}$ Hegel stresses the Böhme's anti-transcendent identification of the Son with the "powers of all natural things" by referring to Böhme's "pantheism of the Trinity". ${ }^{55}$ The divine is present in all things, but in particular human beings, as Böhme makes clear attacking deniers of the Trinity: "You say, there is but one Being in God, and that God has no Son. Open your eyes and consider your selves ... Behold the inward man, and then thou wilt see it most plainly and clearly ... this is the Son which is born in thee." ${ }^{56}$ Böhme in this way represents the "Protestant principle" of "placing the intellectual world

\footnotetext{
${ }^{49}$ According to Hegel's nineteenth-century English translator, Elizabeth Haldane, for Hegel the "point of greatest interest in reading Böhme is the fact that he was able to discover that the conception of abstract identity then in vogue was valueless". Elizabeth S. Haldane, "Böhme and his Relation to Hegel", The Philosophical Review, Vol. 6, 2 (1897), p. 153.

${ }^{50}$ Hegel, Lectures on the History of Philosophy, vol. III, p. 210 (20:113).

${ }^{51}$ Ibid., p. 196 (20:98-9). "In such a way ... all things have this divine Trinity in themselves, not as a Trinity pertaining to the ordinary conception but as the real Trinity of the absolute Idea. Everything that exists is, according to Boehme, this three-fold alone, and this three-fold is everything". Ibid.

${ }^{52}$ Ibid., p. 198 (20:101). In particular Hegel links Böhme's Father to Proclus' “one”. Ibid. (20:100-1).

${ }^{53}$ We might then think of Böhme's One as akin to the universe as a whole when grasped as an "obscure" idea in Leibniz, that is, as that which is presupposed as the reality behind any clear and confused idea.

${ }^{54}$ As quoted by Hegel, Lectures on the History of Philosophy, Vol. III, p. 202 (20:105).

${ }^{55}$ Ibid., p. 170 (20:70).

${ }^{56}$ Ibid., p. 213 (20:115).
} 
within one's own mind and heart, and of experiencing and knowing and feeling in one's own self-consciousness all that formerly was conceived as a Beyond" ${ }^{57}$ Portraying the Son both as an I (ich) and as nothingness (Nichts) by the word play "Icht" - Böhme, says Hegel, had made explicit the "true negativity is the " $\mathrm{I}$ " ${ }^{58}$ In line with this, Böhme calls the One or the Father "the Yes" and the Son "the No" and notes that this One "as the Yes ... would be unknowable in Himself ... without the No. The No is a counter-stroke of the Yes, or of the truth". ${ }^{59}$ This is why any intelligence or willing ("the word" or "the logos") is associated with the Son and not the Father - that is, associated with the finite being who dies. ${ }^{60}$

All this, of course, must have consequences for the traditional idea of God as omniscient, as this idea is dependent on a picture of God that is simultaneously personalistic and transcendent - the imagined occupant of the philosopher's "God's eye view". Hegel's Neoplatonic-Böhmist reading of the Trinity has simply done away with the prototype of such a possible knower. Of course the finitude of all knowing signalled by the "death of God" does not do away entirely with the idea of transcending the finite conditions of knowing. As had Leibniz, Hegel thinks of the passage from immediate perceptual judgments to more mediated ones via the unpacking of implicit inferential relations within the semantic contents of concepts as a movement that transcends the conditions governing the former. But these movements can no longer be pictured as converging on some final "God's eye view" or "view from nowhere", the positivity of which one might appeal to in order to capture what is deficient in those finite modes of knowing.

To attempt to trace the full consequences of Hegel's move would take us well beyond the scope of a short paper, but we might start to grasp one consequence it might have by returning to the idea of omniscience as we have seen it implicit in Jackson's thought experiment involving Mary. The metaphysical dilemma generated by the story of Mary was that she, surely, learns something on leaving her black and white room: she learns what colours are like. But her knowledge had purportedly been complete, so surely, we want to say, her objective knowledge must not have been

${ }^{57}$ Ibid., p. 191 (20:94).

${ }^{58}$ Ibid., p. 206 (20:109).

${ }^{59}$ Ibid., p. 209 (20:112).

${ }^{60}$ Of course the "Holy Ghost" the third person of the trinity, represents the union of the Father and the Son, but this does not detract from the main point - Hegel's criticism of the construal of the God of classical monotheism as a type of large Cartesian mind. 
all the knowledge there was to be had. But this produces a paradox, and the paradox, it would seem, comes from the Kantian conception of omniscience presupposed. It seemed as if Mary, like God the Father, could only extend and so "complete" her knowledge by foregoing knowledge - that is, by accepting the partial, limited and perspectival type of knowledge characteristic of humans into a body of already perfected knowledge. But this is incoherent - the God representing that epistemic telos must have been a false one, and should be replaced by a better one, a conception of a God who already contains negation and limitation within himself. And, of course, if we are, as in Leibniz's metaphor, "mirrors of God", Hegel's reconfigured idea of God must have consequences for our conception of ourselves and our own capacities.

Hegel's new idea of God - a God who necessarily comes into the world as a finite man with real but finite powers of self-transcendence - provides us with a new image in which we can recognize ourselves. In this new image, we see the movement characteristic of our own rationality, the movement from sensuous immediacy to the concept, but as reversed as in a mirror. That is, if our characteristic movement is to move away from sensuousness to the mediation of concepts, God's characteristic movement starts by going in the opposite direction: Like Mary leaving her black and white room, God moves "down" to us, as it were, mirroring our climbing the conceptual tree and "going up" to him. But the next phase of the trinitarian moving image, has Christ, the anthropomorphous God, leaving us to reunite with his father after death, so as to complete him. Consequently, if I am to think of myself as something like an inversion of this triune God, I should think of my characteristic movement as involving an essential moment of return to the limited sensuous existence from which I started. In short, I'm encouraged to give up the effectively idolatrous or perhaps fetishistic idea, that reason is going to liberate me completely from the finitude of human existence, including the finitude of my epistemic existence. Here, as elsewhere, for Hegel the true religion is the enemy of idolatry and false gods. But Hegel's doctrine of the death of God is not the familiar nihilism often associated with this Vorstellung. One's return to the finite, as in the mirror image of Christ's return to his father, does not leave the starting point untransformed. We should resist the lure that conceptual thought will take us to a place free of the limitations of our finite being: the God of that conception is dead. But, grasped in the right way, thought and 
reason can, nevertheless, orient us within our finitude in ways that, by our capacity to conceptualize and reconceptualize our world, ourselves, and our goals, local limitations can be overcome, false gods dispelled, and our finite lives enriched. Something like this seems to be at the heart of the metaphysical consequences of Hegel's theology. 